\title{
Reforming the Security Sectors in South Eastern Europe: Lessons Learned and their Relevance for a Wider Black Sea Area Policy
}

\author{
Dr. Marian Zulean *
}

\section{Introduction}

After the end of the Cold War, the former Warsaw Pact countries committed themselves to building democratic institutions of civilian control over their militaries as part of the democratization process. In the early 1990s, that issue loomed high on the reform agenda because of the fear that the oversized armies, perceived as pillars of the former Socialist state, would seize power and set up dictatorships. Later on, once the basic framework of democratic control of the armed forces was put in place, new issues were incorporated under the rubric of security sector reform (SSR), a broader concept that not only included all the national security agencies but also focused on good governance and efficiency of democratic mechanisms.

On the other hand, Russia withdrew its involvement in Central and South Eastern Europe, allowed the countries in the region to realign and integrate into Western security structures, and allowed more Western assistance to flow into the region. That was not the case of the former Soviet republics, considered by Russia as its "near abroad" area of responsibility.

But the year 2004 brought the double enlargement of NATO and the EU, and countries such as Belarus, Moldova, Russia, and Ukraine became the new eastern neighbors of both NATO and the EU. Meantime, the northern-oriented perspective of enlargement and partnership has been changed by the events of September 11. That one day put the issue of tackling the more complex problems of South Eastern Europe and the Black Sea region higher on the international policy agenda. Also, the Russian leadership is increasingly reluctant to countenance any further involvement of the West on the Northern European dimension, considering that the threats are rather coming from the South. ${ }^{1}$

Once the enlargement was confirmed and eight former socialist countries became EU members - seven of them also being NATO members - both NATO and the EU must develop a policy towards their new eastern neighbors and decide how to anchor them, either by enlargement or by a partnership. What are the challenges, opportunities, and threats in that area? Should they be handled at the bilateral or regional level?

* Dr. Marian Zulean is an associate professor at the University of Bucharest and adviser in the Romanian Government as well as a member of the PfP Consortium's Security Sector Reform Working Group. A version of this paper was presented at the SSR WG conference in Bucharest, in June 2004.

1 See U.S. Department of State, Secretary of Defense Donald Rumsfeld, Press Conference with Russian Minister of Defense Sergei Ivanov, St. Petersburg, Russia, 14 August 2004. Available at: http://www.dod.gov/transcripts/2004/tr20040814-secdef1150.html. 
What kind of role is Russia willing and able to play? What is the commonly agreed upon issue to be tackled by all the actors involved in the area? These are some of the questions that need be answered.

This essay will assess the status of security sector reform in the countries of South Eastern Europe (SEE), draw some lessons from that transition, and argue that a shortterm policy of synergistic efforts to reform the security sectors in the Wider Black Sea area (WBS) should be the common denominator for all the interests in the WBS region. A special partnership of NATO-EU-Russia with the Black Sea actors to reform the security sectors could be a win-win strategy.

\section{Security Sector Reform in SEE}

Bulgaria and Romania began the process of transition from a Communist pattern of civil-military relations (CMR), aiming to build a democratic pattern. The issue of the democratization of CMR ranked high on the national and international agendas but it was replaced, after 2000, with the broader approach of security sector reform. According to Ambassador Theodore Winkler, the security sector reform process is composed of five elements:

1) Reforms are guided by the political leadership in accordance with democratic principle

2) The starting point is a broad view of the term "security"

3) The reform encompasses all security services

4) Security sector reform is a process

5) The reform focuses not only on the structures but also on the human resources. ${ }^{2}$

Although democratization of civil-military relations can be seen as an early stage of security sector reform, both concepts have in common issues such as those of building efficient mechanisms for democratic oversight of the security sector and reforming the post-Communist military. The SSR approach is a fundamentally different way of pursuing state security, a broader approach that takes into consideration both democratization and securitization. The measures taken on efficient resource allocation for development are supplemented by defining norms on how state agencies operate (in terms of transparency, accountability, or civilian oversight).

The reforms started with the adoption of new state constitutions, as early as 1991, and the establishment of the separation of powers, by setting up a democratic framework for civilian control of the armed forces. After the Washington Summit (1999), both countries followed similar paths in their adoption of legislation according to NATO’s annual Membership Action Plan.

2 See Theodore Winkler, "Managing Change. The Reform and Democratic Control of the Security Sector and International Order," in Security Sector Reform: Institutions, Society and Good Governance, eds. Bryden and Fluri (Baden-Baden: Nomos, 2003). 
Although they began at different starting points, both countries built similar institutions of democratic control. Their parliaments are the main institutions for implementing democratic control of armed forces through their plenary legislative activity or directly through their defense commissions. Their presidents are commanders in chief of the armed forces, while the prime ministers and governments implement defense policies. The presidents receive advice on security issues from national security councils. The judiciaries, through their various institutions, play an important role in controlling the military by, for example, ruling on whether they respect constitutional rights.

Thus, the most important mechanisms of democratic control are considered those in the fields of budgetary allocations and transparency. While the former is a matter of parliamentarian control, with additional help from the executive and judicial audit bodies, the latter is related to the military's openness and its accountability toward civil society. The issue of transparency in South Eastern Europe became more important after 2000, when the Stability Pact adopted the Budget Transparency Initiative.

Secondly, on the military level, the reform challenge was to have well-defined missions, determined by a legitimate government, while maintaining specific combat expertise, clear rules of promotion, and a new system of military education and training.

Changing the role, missions, and defense planning system was an important challenge for South Eastern European countries. Each state started the process from a different foundation. While Bulgaria was a very loyal Warsaw Pact ally (the Bulgarian Popular Army's mission was to defend socialism), Romania was a maverick country within the Warsaw Pact with a doctrine focused on territorial defense and total war. The (new) constitutional provisions in both states define the new role of the armed forces as guaranteeing the sovereignty, security, and independence of the state. Clear security strategies and planning, programming, and budgeting systems were adopted in the late 1990s with Western help, after the states' candidacy to join NATO became a serious matter.

Structural change. New missions brought the requirement of re-tailoring military organizations. Both Romania and Bulgaria had to downsize their large military forces. There were many plans and proposals, but the catchphrase for both countries was that they should create a "flexible force, interoperable with NATO." Today, both countries have designed similar types of active force organizations, with a General Staff, integrated within the ministries of defense, with three branches: army, navy, and air force.

Changing the system of education and training is a core part of any process of professionalization. Sound concepts of human resource management and military educational reforms were elaborated in the mid-1990s, with U.S., U.K., German, Dutch, or French assistance. Both Romania and Bulgaria had to restructure and change the curricula and the structure of the former military academies. To train conscripts or professional soldiers in the spirit of NATO, some regional training centers have been organized, such as the Regional Center for Partnership for Peace Training in Bucharest (set up with British assistance) and the Regional Center for Management of Defense Resources (set up with U.S. assistance).

In conclusion, it can be assessed that internal and external forces required the democratization of civil-military relations and the reform of the security sectors. While 
the internal forces ignited the reform and supported it, Western assistance was fundamental in providing ideas, guidance, and funds. Let's describe further the role of Western assistance in democratization of CMR and SSR.

\section{The Role of Western Assistance in Security Sector Reform}

Although there were no specific assistance programs in Western nations to promote CMR and SSR, these efforts were incorporated into other programs. In Thomas Carothers' terms, those programs have had a double dimension: from the top-down (fostering institutions and changing the constitutions) and from the bottom-up (preparing civil society to deal with security issues and to assume civilian control). ${ }^{3}$ The assistance programs were pursued either at the multilateral or bilateral levels.

The United Nations, the Organization for Security and Cooperation in Europe, and the European Union were institutions actively involved in supporting security sector reform in South Eastern Europe, but North Atlantic Treaty Organization (NATO) was the most active and influential. NATO has been the main multilateral organization able and interested to promote a democratic civil-military relationship. It acted more like a "carrot" for South Eastern European countries in search of integration into the more prosperous Western world. Aware of the lack of civilian expertise in the region, NATO ran a large number of activities to develop civilian expertise in security. NATO has strengthened its information programs for partners, including conferences and seminars (at the NATO Defense College and at the NATO School (SHAPE) in Oberammergau), visitation programs, fellowships, etc. NATO was and is also making another long-term investment in European stability through its ongoing enlargement process. The Study of NATO Enlargement (1995) openly claimed that its goal is to support democratic reforms in Central and Eastern Europe, including democratic control of armed forces, and to set some benchmarks for the countries that desire to join NATO.

The main instrument of NATO assistance to countries in Central, Eastern, and South Eastern Europe has been the Partnership for Peace (PfP). Its main goals were to expand and intensify political and military cooperation throughout Europe, increase stability, diminish threats to peace, and build strengthened relationships by promoting the spirit of practical cooperation and commitment to democratic principles that underpin the Alliance. In the sense of a clear roadmap for reform, the Membership Action Plan (MAP) was essential for Romania and Bulgaria. MAP was the instrument that guided the reform in a structured manner, broadened the concept of "security," and extended the reform and its evaluation to the five broad items mentioned above.

After the Kosovo crisis, the West committed to solve the problems in the Balkans, and launched the Stability Pact for South Eastern Europe at Cologne, on 10 June 1999, which was primarily an EU-sponsored initiative. The Stability Pact aims at strengthening countries in South Eastern Europe in their efforts to foster peace, democracy, respect for human rights, and economic prosperity, in order to achieve stability in the

See Thomas Carothers, Aiding Democracy Abroad (Washington, D.C.: Carnegie Endowment for International Peace, 1999). 
whole region. However, although Bulgaria and Romania saw the European Union and NATO as two faces of the same actor - the West - and directed their energy toward joining those institutions, the support for the Iraqi war was an issue that created a rift among the trans-Atlantic actors and could have endangered the goal of integration.

Although many European countries, such as the U.K., Germany, France, Italy, and the Netherlands, were very supportive of Romania and Bulgaria, by far the most important donor for defense and security sector reforms was the United States. U.S. bilateral assistance was delivered both for the development of civil society and for the reform of the military. In the field of civil society development, USAID was the most important provider of funds through its Global Bureau's Center for Democracy and Governance, promoting the democratization of civil-military relations, demobilization, and reintegration of the militaries. It administrated Congressional funds under the Supporting East European Democracies (SEED) Act. Nongovernmental organizations, such as the National Endowment for Democracy, the National Democratic Institute, and the International Republican Institute were also involved in civil society capacity building.

In the field of military reform, the Pentagon ran important programs such as Mil-toMil, the Warsaw Initiative, and International Military Education and Training (IMET). The last one was important because it supported military personnel to come to U.S. military academies and not only face first-hand exposure to military professionalism but to understand the role of the military in a democracy. According to some Pentagon information between 1993 and 2003, the Romanian military received more than US\$79 million, and recently received US\$11.5 million under the Freedom Consolidation Act.

The democratization of CMR and SSR are fundamental aspects of promoting stability and democracy. Although the countries of South Eastern Europe started from different bases of development and civil society, it looks as though strong support is building for the internal forces to join Euro-Atlantic institutions, particularly via NATO's "open door policy," and clear programs of assistance are essential in the successful reform of the security sectors. The next part of this essay will argue why the wider Black Sea area should be a priority for both NATO and the EU's strategic thinking and action, and will offer several policy recommendations on pursuing security sector reform in this region.

In order to have a clear and sound policy towards the wider Black Sea area, an important pre-requisite is a shared vision on the part of the West and the countries in the region. The integration of Bulgaria and Romania was based on the domestic requirements of both countries, supported by a common vision in the West, particularly the American vision presented in 2001, to include within Western security structures the countries from the Baltic to the Black Sea. But at present we have a confused vision in both Black Sea countries, with similarly confused vision on the part of NATO and the EU. 


\section{Looking North or South? The Geopolitical Dilemma}

The Black Sea littoral has been neglected as a geopolitical region, probably since the Ottoman, Tsarist, and Austro-Hungarian empires fought in the Crimean War (1856). After the end of the Cold War, what was then seen as the unitary "Eastern Bloc" was divided for different analytical and policy reasons. The Visegrad Group, Central Europe, South Eastern Europe, Western Balkans, and Newly Independent States were a few of the analytical and policy clusters. However, the Black Sea was not seen as an important region until recently (though some institutions, such as the Black Sea Economic Forum [BSEC], Blackseafor [PfP], or economic projects such as TRACECA and INOGATE were created). But the dual enlargement of NATO and the EU brought the issue of the Black Sea region to the head of the academic and policy agenda. Some of the think tanks established research departments or research topics in order to explore potential policies towards the Black Sea and South Caucasus area.

The recent enlargement of both NATO and the EU brought an increase in interest in the region. In the Final Communique of NATO's Istanbul Summit, article 41 states: "We note the importance of the Black Sea region for Euro-Atlantic security. Littoral countries, Allies and Partners are working together to contribute to further strengthening security and stability in the area..."4

After the EU Commission presented its communication on "Wider European Neighborhood: A new framework for relations with our Eastern and Southern Neighbors," it recently revealed further steps towards these new neighbors, methods to meet ENP goals, and resources. In my view, all the cited provisions are either general declarations or bilateral measures, and none of them take a truly regional approach.

However, a recent American policy paper, written by Ronald Asmus and Bruce Jackson, tries to overcome these shortcomings. ${ }^{5}$ After the explanation of why the West neglected the region, the paper starts to define the Black Sea region as a Euro-Atlantic area of interest and builds a strong moral and strategic case for a unified Euro-Atlantic strategy towards the region.

The strategic case is based on two arguments: the need to complete the job of consolidating peace and democracy in Europe, and the necessity of addressing the most dangerous threats to the Euro-Atlantic community (the authors call the Black Sea the "new Fulda Gap"). The moral case is based on the arguments of completing the vision of Europe "whole and free" and the democratization of Russia by anchoring it to the Black Sea area.

Although the vision of the region and the arguments are clear and timely, the policy recommendations were invalidated by recent events in Georgia, Trans-Dniester, and by the Istanbul Summit, which paid little attention to the area. My assumption is that Asmus and Jackson's paper underestimated the role of and leverage exerted by Russia, as

4 NATO, Istanbul Summit Communiqué, Press Release 069, 28 June 2004; available at http://www.nato.int/docu/pr/2004/p04-096e.htm

5 See Ronald Asmus and Bruce Jackson, "The Black Sea and the Frontiers of Freedom," Policy Review (June 2004). 
well as the vested interests of many other actors. The present paper considers that, after defining a strategic vision for the wider Black Sea region, the first step in the reform process should be to start with an easy issue of common interest and high potential: security sector reform.

The first assumption behind this recommendation is that the majority of the former USSR countries, except the Baltic States, are lagging behind their Western neighbors in economic and political development. Some of them are "frozen" at the level of "glasnost and perestroika." Weak state institutions, corruption, prospects for authoritarianism, organized crime, and trafficking in drugs and weapons are some of the features that can hardly be tolerated at the border of an enlarged NATO and EU. A common denominator to address all these matters is the reform of security. Transparency and civilian democratic control of the security sectors continues, in a more organized and Western manner, the policies of perestroika and glasnost.

The second assumption is that the policy recommendations for a regional Black Sea approach should avoid the GUUAM experiment, but rather learn from its experience, taking into consideration the common interests of the main stakeholders. The economic interest of securing an energy transport corridor from the Caucasus to Europe should be openly recognized. In fact, it could deliver the resources for change and development for all interested actors.

\section{Why to Pursue Security Sector Reform in the Black Sea Region}

Why should security sector reform be pursued in the wider Black Sea area? First of all, the broader approach to security sector reform has been a successful policy for the candidate countries to NATO, after adoption of the Membership Action Plans. Some partial measures related to SSR were adopted by the Black Sea states too, under either the aegis of OSCE or PfP plans.

However, the lack of prospects for either NATO or EU membership is an important obstacle to implementing a comprehensive SSR policy. Therefore, a clear and comprehensive policy of SSR, under a special partnership in the Black Sea region with Russian involvement and Western assistance, would be recommended.

Second, any moral and strategic case should recognize the role of Russia and the interests of the local actors, but the Russian taboo against involving the UN, EU, NATO or any Western institution in its "near abroad," particularly in solving the "frozen conflict," must also be defused. Russia's "near abroad" has become Europe's de facto "near abroad," and there are already American troops in place in the region, and the Black Sea countries have participated in many PfP exercises or "coalitions of the willing."

Third, the SSR process is a win-win strategy. Russia will share the burden of securing stability (saving resources) and will be recognized as a regional leader that shares the peace and stability dividend. The aspirations of the new nations for stability and development will be met, while NATO and the EU could contribute further to their moral and strategic objectives of building a secure and free Europe. 
Lastly, some important steps have already been taken, on both the academic and policy levels. The Dutch Center for European Security Studies is pursuing a research project called "Needs and Options for Security Sector Transparency in Ukraine and Moldova" (NOSTRUM), which is trying to investigate the best practices from Bulgaria, Romania, and Slovakia's reforms and to present policy recommendations to Ukraine and Moldova's policymakers. ${ }^{6}$ Also, a regional collaborative project called "Black Sea-Caspian Region: Security Challenges and Democratic Control" is going to create a coordinated network of analytical centers and work to promote SSR. Moreover, the SSR-WG of the PfP Consortium hosted, in November 2003, a conference on SSR in the Southern Caucasus that investigated the challenges and vision of SSR in the Southern Caucasus.

\section{Conclusions and Policy Recommendations}

The democratization of civil-military relations and security sector reforms in South Eastern Europe could be considered a success story. The clear vision of integration into NATO and the EU, bolstered by popular support and elite understanding, was corroborated by Western vision, guidance, and assistance to pursue the reforms. The dual enlargement of NATO and the EU, the war on terrorism, and economic interests opened a window of opportunity for a special partnership of the Western institutions, Russia, and local actors in the wider Black Sea area. However, the flawed understanding of strategic interests and Cold War mentalities are obstacles to solving the region's problems and developing the area.

This essay argued that, for the moment, further enlargement of NATO and the EU is not the answer to developing the region, but rather a special partnership for security and development. Although some countries, such as Ukraine, have already special partnerships with both NATO and the EU, a regional approach based on mutual interest and understanding is possible (as the Visegrad, or V-10, informal groups had in the 1990s).

However, the strategic vision for a wider Black Sea policy should be agreed upon by the actors involved. Probably the best venue for this could be the next G-8 Summit. After that, a plan for SSR should be designed and implemented. The plan should first reinforce the OSCE's Code of Conduct commitments, IPPs/PfP plans of reform, and then should start solving the "frozen conflicts" of the area by balancing the actual negotiating format with some Western institutions, such as the EU. The plan should also address the issues of border security and management; military and security agency reform and training; and changing the roles, missions, and democratic oversight of defense planning, concomitant with the implementation of norms related to transparency and accountability and preparation of the civilian elite to accomplish democratic oversight missions.

6 See Center for European Security Studies, "Security-Sector Reform and TransparencyBuilding: Needs and Options for Ukraine and Moldova," Harmonie Paper 17 (2004). 
The first step in the plan would be the adoption and implementation of the full norms and legal framework of democratic CMR, according with the OSCE's Code of Conduct, followed by a commitment and assistance from Western institutions and neighboring countries. A special status for the Black Sea countries within PfP, like that recently created for the Western Balkans (Adriatic Charter), would be appropriate. Some "dormant" regional alliances, such as GUUAM, could be reinforced and re-tailored to the Black Sea and South Caucasus context. Even though Ukraine has special status with both NATO and the EU, from the latest experience of V-10 countries, the lesson can be drawn of acting as a group in order to receive special attention from the West.

NATO, EU, and U.S. involvement is essential, but Russian consultancy and involvement is necessary (without giving it veto power). Besides Western assistance, the regional participation of Black Sea countries within SEE regional initiatives, such as SECI, could easily help the transfer of knowledge. To facilitate immediate assistance, the cooperation of the Western donor institutions with a regional sub-contractor state, such as Poland for Ukraine and Romania for Moldova, could be a workable solution. 
THE QUARTERLY JOURNAL

\section{Bibliography}

Asmus, Ronald, and Bruce Jackson. "The Black Sea and the Frontiers of Freedom." Policy Review (2004).

Carothers, Thomas. Aiding Democracy Abroad. Washington, D.C.: Carnegie Endowment for International Peace, 1999.

Winkler, Theodore. "Managing Change. The Reform and Democratic Control of the Security Sector and International Order." In Security Sector Reform: Institutions, Society and Good Governance. Baden-Baden: Nomos, 2003. 